\title{
An item Teaching Method-based Evaluation Scheme Design of the Teaching Materials for Accounting Computerization in Independent College
}

\author{
Liu Yichen \& Chen $\mathrm{Na}$ \\ Shijiazhuang University of Economics \\ Liu Yiqing \\ Shijiazhuang Information Engineering Vocational College
}

\begin{abstract}
The teaching reform of item teaching method is conducted in the independent colleges of China, like a raging fire. This paper, based on the teaching experience of Accounting Computerization in independent college, from the perspective of an educator, makes a design for Accounting Computerization teaching material choosing and evaluation scheme in independent college under the item teaching method.
\end{abstract} KEYWORD: item teaching method; independent college; accounting computerization

\section{TEACHING MATERIAL DESIGN}

Teaching material is the source of teacher's teaching and students' learning as well. It is one of the main references for both teacher and students. Various item teaching method-based Accounting Computerization teaching material designed for independent college emerged in the market to meet the independent college's item teaching method reform in recent years, but the quality of these teaching materials are not satisfactory.

\subsection{Teaching software selection design}

The teaching material for accounting computerization in dependent college is usually a popular financial software and takes no consideration of other software so that the students know little about the other software's framework and development and have a poor software flexibility. Therefore, according to the regional application of ERP, the teaching material should include two or more software with their newly updated versions to help the students know the dynamic development of software timely.

\subsection{Teaching material organization design}

The content of the teaching materials for Accounting Computerization used in dependent college is out of date, not prospective, and it is different from the traditional teaching materials simply with its new name of "item", "unit" or "learning situation". This kind of teaching material is generally written according to the discipline knowledge system, focuses on the computer operation steps of business information, accounting entries and so on, the essence of which is still a software instruction or training book. It may be useful in promoting the students' software operation ability, but the students lack real case analysis, organization and induction ability. It suits the traditional teaching but not the item teaching method.[1] The item teaching methodbased teaching materials must be based on the enterprise working process, set up reasonable teaching items and typical units, select simulation case materials such as enterprise introduction, organization chart and some appropriate amount of questionable original certificate (fake invoice, reimbursement of excess, etc.), and provide the students' opportunity to organize materials and solve problems themselves, strengthening their professional judgment, remedying the defects of too much operation steps and little materials organization, checking and monitoring.

\subsection{Teaching content design}

The Accounting Computerization teaching materials now used in independent college include mainly industrial enterprise's economic activities of general ledger, reporting, salary, fixed assets, accounts receivable and payable systems, commercial enterprises and supply chain are seldom included, which goes against the integration need of enterprise's finance and business. Therefore, the teaching content design should pay attention to the following:

The content of teaching materials should be expanded effectively, and the item scope should be enlarged also, to guide the students acquiring multiple aspects of knowledge. 
The teaching materials should integrate organically the software operation and enterprise management concepts, letting the students know what management needs the software set meets, include timely the new knowledge, techniques, methods and requirements of job, and formulate a more practical item-based school teaching materials. The teaching materials should conclude the difference from manual processing, and the students learn through comparing, which can bring a deep understanding of knowledge.

To be more practical, the teaching materials should include examinations, for example, certificate examination of accounting professional.

\subsection{Teaching material type design}

Although there are numerous quality teaching materials of Accounting Computerization written for independent college or even national eleven-year plan, the regional economic development, enterprise informatization degree and students an independent college facing is different from each other, the school teaching materials under the cooperation of school and enterprise should be more practical and targeted.

\subsection{Other teaching materials design relying on the excellent course construction}

Relying on the excellent course construction, the use of various modern internet teaching resources such as FTP network platform and supply chains network, interscm.com, Kingdee's youshang.com, UFIDA's e-learning and e-mail expands the teaching from the classroom to the extra curriculum, digitalizes the physical form or put directly the excellent course website of relevant polices, examination information on certificate of accounting professional, curriculum standard, plan, outline, courseware, unit design, examination papers, case base, training materials, assignment, guidance materials, academic papers, videos, teaching records, the previous outstanding works of the students, and so on. The students can $\log$ in and use these teaching materials at anytime and anywhere. The plentiful internet resources provide the students' convenience of self-studying and save the copy cost at the same time, which realizes the green teaching and a high efficient sharing of teaching materials.

\section{EVALUATION SCHEME DESIGN}

Evaluation is the most direct means of inspecting the teaching achievements. J.S. Bruner, the American famous cognitive psychologist and philosopher of education, pointed out that learning is a process and advocated finding learning, paying attention to the students' intellectual development, and creating initiative and creative spirit during the learning process. The evaluation of traditional accounting computerization course in independent college is generally through a closed-book examination or submitting account books, a summative evaluation form totally controlled by the teacher, focusing on examining the students' theoretical knowledge, but unable to evaluate the students' computer practice skills, which neglects Bruner's education ideas and goes against the item teaching method. It becomes necessary to reform the traditional evaluation polices. [2]

\subsection{Design principle}

In order to best evaluate the students' learning under the item teaching method, a combined evaluation form of formative and summative evaluation should be adopted, which takes the course's high practicalness into consideration, utilizes effectively the teaching resources of training room in school and training base and part-time teachers outside school, carries out a comprehensive reform from the aspects of evaluation subjective, content and place, introduces the enterprise evaluation standard and social certificate examinations, and with the enterprise's cooperation, tries to be of multiple subjective, forms, open and vocational in the field of evaluating the students' theoretical knowledge and other abilities of ERP operation ability, case analysis and handling ability, and vocational ability. The cultivation of the students' practical ability is emphasized and this form of evaluation helps the students' knowing clearly their learning objective, increasing learning initiative, emphasizes the cultivation of the students professional ability, and corresponds to the accounting computerization education target in independent college.

\subsection{Evaluation subjective design}

\subsubsection{Students'self-evaluation}

The item teaching method-based accounting computerization course in independent college requires the students to make a dynamic selfevaluation of enterprise investigation, ERP software operation ability, cooperation ability and task completion ability, and write a project report. As a learner, the student, through the comparative selfevaluation of knowledge accumulation and ability improvement, introduces his or her individual success to the others and makes up initiatively his or her individual insufficiency.

\subsubsection{Team evaluation}

Team evaluation means that the team member evaluates each other in their own team. In the item 
teaching method-based accounting computerization course, the completion of a project needs all the team members' participation in enterprise investigation, role location, scheme making, materials collection, project implementation, discussion, solving problems and results report. The participation of all the team members can initiative their cooperation interest and enhance the task completion ability.

\subsubsection{Evaluation from the other teams}

Each student should be evaluated by the individual student from other teams. In the item teaching method-based accounting computerization course, through the extensive exchange and evaluation between teams, each student is possible to get recognition or praise from the others or receive criticism and corrections. The others' evaluation mobilizes the students' learning activeness, and trains their psychological endurance also. Evaluation from the others can help the individual promoting his or her ability and self-confidence, and at the same time, evaluating the others can help the others promoting their analysis and judging ability. Both sides have a positive emotional experience.

\subsubsection{Teacher oriented evaluation}

The item teaching method-based teacher oriented evaluation should give a full play of the twopromoting guiding role in the students' learning and the teacher's teaching. Classroom observation, after class interview, job analysis, operation, practice, and other teaching forms should be used and the evaluation method should be multiple. The description of evaluation result is better in encouraging language, playing the evaluation's encouraging role. The teacher should admit the students' individual difference, protect their selfrespect and confidence and adjust the teaching process according to the evaluation results.

\subsubsection{Experts outside school involved evaluation}

The accounting computerization course in independent college emphasizes on cultivating the students' social practice ability. A large proportion of practical teaching, such as project training, internship and enterprise investigation, needs the school and enterprises' cooperation, therefore, the item teaching method-based evaluation should include both the teacher's one and that from the enterprise. The participation of part-time teachers, enterprise accountant, and experts from the institute of CPA, software companies like UFIDA and Kingdee, the Ministry of Information Industry and so on, can ensure a professional, scientific and impartial evaluation.

\subsubsection{Certificate examination evaluation}

Criterion-referenced tests, such as the accounting computerization subject testing in certificate examination of professional accounting, NCAE, $\mathrm{KCP}$ of Kingdee, application expert certificate of UFIDA ERP software operation skill competition and sand table series, can be taken as the evaluation subjective of the item teaching method-based accounting computerization course in independent college.

\subsection{Evaluation content and form design}

The evaluation forms of the item teaching methodbased accounting computerization course in independent college include attendance, assignments, examination papers, stage training testing, stage practice testing, internship testing, certificate examination ,interview, etc., a comprehensive evaluation of the students' knowledge, ability and professional quality.

\subsubsection{Knowledge evaluation}

The students' knowledge is evaluated according to the assignments, examination papers, certificate, interview and the specific application of theories in project implementation, stage training, stage practice and internship.

\subsubsection{Ability evaluation}

The students' ability is evaluated with the computerized accounting job task as the criterion, in the case of integration of enterprise's finance and business. The students' case data management and analysis ability during the process of project implementation, stage training, stage practice and internship, and ERP software processing ability.

\subsubsection{Professional quality evaluation}

The students' professional quality is evaluated mainly according to the aspects of enterprise investigation, materials collection, social skills, learning attitude, innovative consciousness, cooperation spirit, and professional consciousness shown when completing projects.

The tests for stage practice, internship and so on can be evaluated through the combination of submitting practice results and the teacher's commenting. The evaluation at the end of the semester uses the enterprise evaluation standard, adopting the examination systems of the Ministry of Finance's accounting computerization in certificate of professional accounting or the Ministry of Information Industry's NCAE, which is objective and impartial and can help the students obtain professional qualification for computerized accounting occupations. 
It is impossible to make a uniform evaluation index system for the item teaching method-based accounting computerization course in independent college, which needs a long time's exploration and improvement. The table 1shows the evaluation index setting for each evaluation item:

Table 1 Evaluation index and weight design table

\begin{tabular}{|c|c|c|c|c|c|c|c|}
\hline \multirow{2}{*}{ NO. } & \multirow{2}{*}{$\begin{array}{c}\text { Evaluation } \\
\text { content }\end{array}$} & \multirow{2}{*}{ Weight } & \multirow{2}{*}{ Evaluation index } & $\begin{array}{l}\text { Evaluation } \\
\text { grade }\end{array}$ & & & \\
\hline & & & & $\begin{array}{c}\text { Outstanding } \\
100-85\end{array}$ & $\begin{array}{l}\text { Good } \\
84-75\end{array}$ & $\begin{array}{c}\text { Acceptable } \\
74-60\end{array}$ & \begin{tabular}{|l} 
Disappointing \\
$59-0$
\end{tabular} \\
\hline 11 & \multirow{2}{*}{$\begin{array}{l}\text { Knowledge } \\
\text { evaluation }\end{array}$} & \multirow{2}{*}{0.2} & $\begin{array}{l}\text { Think actively and solve kinds of difficulties by } \\
\text { using flexibly the existing knowledge in the process } \\
\text { of project implementation. }\end{array}$ & & & & \\
\hline 2 & & & $\begin{array}{l}\text { Summarize carefully and evaluate correctly the } \\
\text { completion of project, and induce and grasp the } \\
\text { relevant theoretical knowledge. }\end{array}$ & & & & \\
\hline 3 & \multirow{4}{*}{$\begin{array}{l}\text { Ability } \\
\text { evaluation }\end{array}$} & \multirow{4}{*}{0.5} & $\begin{array}{l}\text { Share, analyze and induce the materials collected } \\
\text { and develop a feasible scheme. }\end{array}$ & & & & \\
\hline 4 & & & $\begin{array}{l}\text { Report and expose project results actively, and } \\
\text { express explicitly. }\end{array}$ & & & & \\
\hline 5 & & & $\begin{array}{l}\text { Succeed in labor division according to the role, and } \\
\text { complete the task accurately and skillfully. }\end{array}$ & & & & \\
\hline 6 & & & Normative, neat and correct project results. & & & & \\
\hline 7 & \multirow{6}{*}{$\begin{array}{l}\text { Professional } \\
\text { quality } \\
\text { evaluation }\end{array}$} & \multirow{6}{*}{0.3} & $\begin{array}{l}\text { Carry out practically the designated topics of } \\
\text { enterprise investigation and have a strong social } \\
\text { ability. }\end{array}$ & & & & \\
\hline 8 & & & $\begin{array}{l}\text { Adopt various effective ways to collect abundant, } \\
\text { adequate and accurate information to meet the } \\
\text { research need. }\end{array}$ & & & & \\
\hline 9 & & & Evaluate objectively himself/herself and the others. & & & & \\
\hline 10 & & & $\begin{array}{l}\text { Participate actively kinds of tam discussion and } \\
\text { cooperate smoothly with the others. }\end{array}$ & & & & \\
\hline 11 & & & $\begin{array}{l}\text { Have a clear learning goal and active learning } \\
\text { attitude. }\end{array}$ & & & & \\
\hline 12 & & & $\begin{array}{l}\text { Establish an overall occupation literacy of } \\
\text { environmental protection consciousness, } \\
\text { autonomous learning and creative spirit. }\end{array}$ & & & & \\
\hline
\end{tabular}

In order to avoid the students' cheating in assignments, testing or stage training testing by copying or screenshot the others' account books through the internet or portable storage devices, which makes the evaluation result unfair, the students are required to set the account books number after his or her student number and name the operator after his or her own real name in business processing, according to the characteristic of ERP that the number of account books and operator is unique and cannot be changed.[3] Sometimes the account books cannot be imported or the teacher cannot score caused by troubles like limited saving space, account books copying and system fault. In order to avoid these problems, the practice results can be submitted to a named FTP as a word document or a full screenshot of the operation window, which is paperless and green.

The specific evaluation form, subjective and place design is shown in the figure 1:

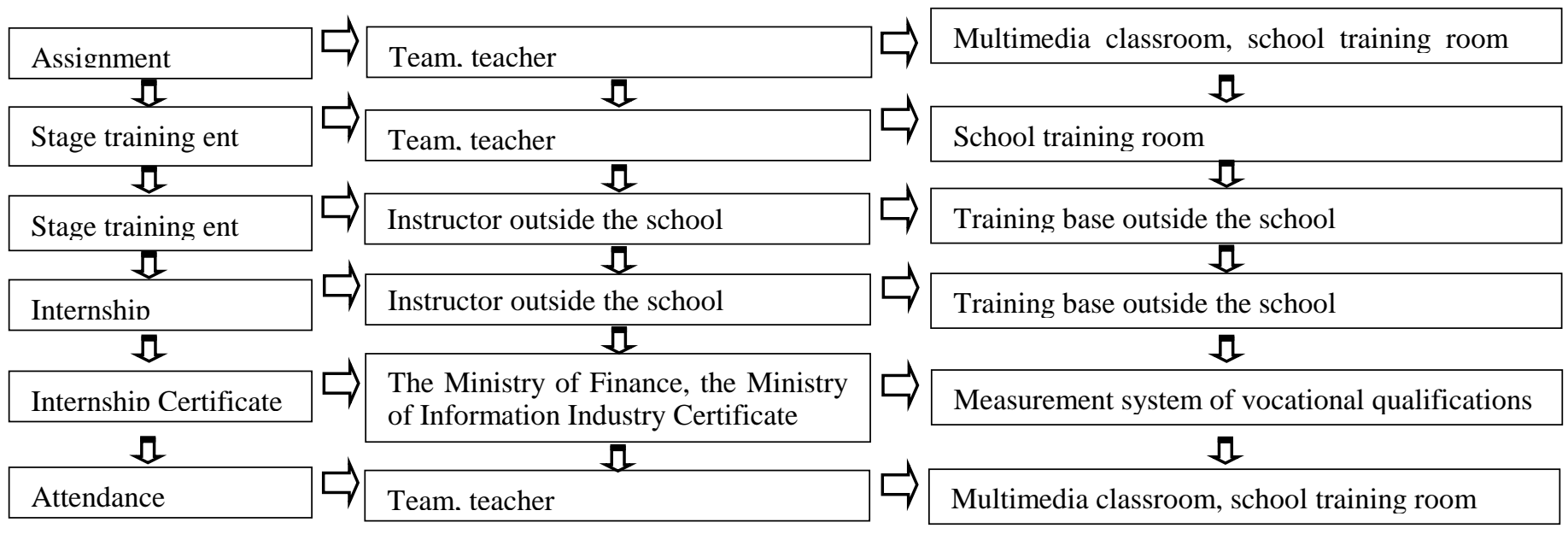

Figure 1 The test form, subject and location design 


\section{EVALUATION SCORES DESIGN}

The final evaluation of the item teaching methodbased accounting computerization course contains day-to-day class scores and scores at the end of the semester; the former counts $60 \%$ in the final evaluation, focusing on the process evaluation, including attendance, assignments and tests, stage training testing, stage practice testing, and internship; the latter counts $40 \%$ in the final evaluation, involving certificate examinations of NCAE, ERP application qualification, and certificate of professional accounting. The specific evaluation scores structure is designed in the Figure 2

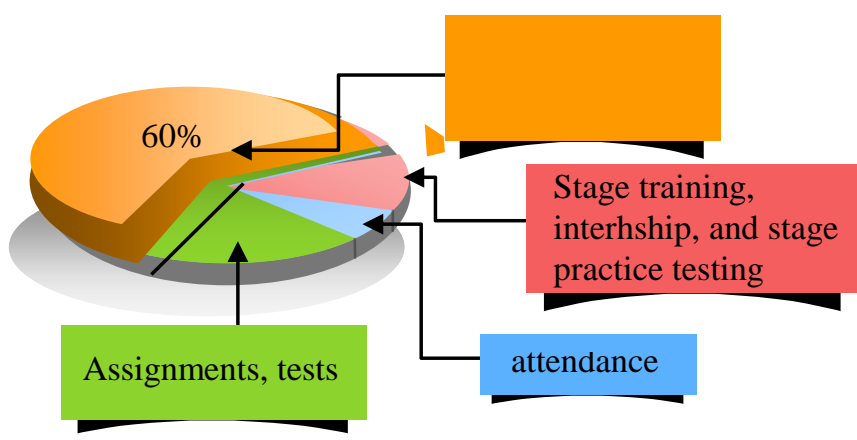

Figure 2 Examination results of structure design

The evaluation of assignments and tests includ es the comprehensive test results of the students' theoretical knowledge, ability and professional $\mathrm{q}$ uality in the implementing of each project. The calculation formula is as follows:

$$
\mathrm{C}=\sum \mathrm{Ai} \times \mathrm{Pi} \quad(\mathrm{i}=1,2,3,4,5 \ldots)
$$

$\mathrm{C}$, in the formula, is the comprehensive evaluation scores of the assignments and tests of the item teaching method-based accounting computerization course. It is divided into 4 grades, outstanding (100-85), good (84-75), acceptable (7460 ) and disappointing (59-0). $\mathrm{i}$ is a subject number of the accounting computerization course, and $\mathrm{Ai}$ is the assignments and tests score of Subject.i. The assignments and tests score is determined by the students self-evaluation, team evaluation, evaluation from the other teams and the teacher's instructive evaluation according to the given evaluation indexes, in which scores of the former three ways of evaluation count $20 \%$ respectively and the last one $40 \%$. $\mathrm{Pi}$ is the weight of Subject.i $(\mathrm{P} 1+\mathrm{P} 2+\mathrm{P} 3+\mathrm{P} 4+$ $\mathrm{P} 5+\ldots=1)$ in the comprehensive evaluation scores of the accounting computerization course.

The weight of scores of items in various learning situations in the accounting computerization course is shown in the following table:

The attendance score is averaged to each class hour according to the total class hours of each semester. Being absent without any reason weighs 0 , being absent for illness or private affairs weighs half of the average score, thus, each student's attendance score is calculated. If the absent hours exceed $1 / 3$ of the total class hours, whatever the reason is, this student's attendance score is 0 .

The score of stage training, stage practice and internship testing is graded into 4 levels: outstanding (100-85), good (84-75), acceptable (74-60) and disappointing (59-0).

Certificate examination scores are given by the system directly.

This paper is the author's experience summary, while as there is no fixed model for any subject in the item teaching method, there still needs further exploration.

\section{REFERENCES}

[1] Tan Qian. The application of item teaching method to the accounting computerization course. Population \& Economics, 2011, 1: 119-120.

[2] Jin Jingmei. The evaluation of item teaching method in higher vocational education. China Modern Educational Equipment, 2010, 1:161-162.

[3] Zhou Yan, Peng Xuexue. The application of item teaching method in higher vocational accounting computerization course. Journal of Luohe Vocational Technology College, 2010, 3:149-150. 